\title{
Methane emissions of stored manure from dairy cows fed conventional or brown midrib corn silage
}

\section{Benchaar* and F. Hassanat}

Agriculture and Agri-Food Canada, Sherbrooke Research and Development Centre, 2000 College Street, Sherbrooke, QC, Canada J1M 0C8

\section{ABSTRACT}

The objective of this study was to examine the effects of feeding conventional corn silage (CCS) or brown midrib corn silage (BMCS) to dairy cows on $\mathrm{CH}_{4}$ emissions from stored manure. Eight lactating cows were fed (ad libitum) a total mixed ration (forage:concentrate ratio 65:35; dry matter basis) containing 59\% (dry matter basis) of either CCS or BMCS. Feces and urine were collected from each cow and mixed with residual sludge obtained from a manure storage structure. Manure was incubated for 17 wk at $20^{\circ} \mathrm{C}$ under anaerobic conditions $\left(\mathrm{O}_{2}\right.$-free $\left.\mathrm{N}_{2}\right)$ in $500-\mathrm{mL}$ glass bottles. Methane emissions and changes in chemical composition of the manure were monitored during the incubation period. The total amount of feces and urine excreted was higher for cows fed BMCS than for cows fed CCS [8.6 vs. 6.5 $\mathrm{kg} / \mathrm{d}$ of volatile solids (VS)]. Manure from cows fed BMCS emitted more $\mathrm{CH}_{4}$ than manure from cows fed CCS (173 vs. $146 \mathrm{~L} / \mathrm{kg}$ of VS) throughout the incubation period. Similarly, VS and neutral detergent fiber losses throughout incubation were higher for manure from cows fed BMCS versus cows fed CCS (37.6 vs. $30.6 \%$ and 46.2 vs. $31.2 \%$, respectively). Manure $\mathrm{NH}_{3}$ concentration ( $79 \%$ of total manure N) was not affected by corn silage cultivar. Results of this study show that using a more digestible corn silage cultivar (BMCS vs. CCS) may increase the contribution of manure to $\mathrm{CH}_{4}$ emissions, and may offset gain achieved by reducing enteric $\mathrm{CH}_{4}$ emissions.

Key words: manure, methane emission, brown midrib corn silage

\section{INTRODUCTION}

Methane emissions from Canadian agriculture (1.2 Mt of $\mathrm{CH}_{4} / \mathrm{yr}$ ) originate mostly from enteric fermenta-

Received April 17, 2019.

Accepted July 5, 2019.

*Corresponding author: chaouki.benchaar@canada.ca tion $(83 \%)$ and to a lesser extent from manure management $(17 \%)$. These emissions represent $48 \%$ of total greenhouse emissions of the Canadian agriculture (Environment Canada, 2015a). Since these emissions are the major contributor to agricultural $\mathrm{CH}_{4}$ emissions, several nutritional strategies have been put forward to mitigate enteric $\mathrm{CH}_{4}$ production from dairy cows (Beauchemin et al., 2009; Benchaar et al., 2014; van Gastelen et al., 2015). However, the effect of these strategies on $\mathrm{CH}_{4}$ emission of manure needs to be assessed to ensure that reducing enteric $\mathrm{CH}_{4}$ emissions would not be counterbalanced by increased $\mathrm{CH}_{4}$ emission from manure management. Studies investigating the effect of enteric $\mathrm{CH}_{4}$ mitigation strategies on $\mathrm{CH}_{4}$ emissions from stored manure are scarce.

According to IPCC (2006), $\mathrm{CH}_{4}$ emission factor $(\mathrm{kg}$ of $\mathrm{CH}_{4}$ /cow per year) of manure management depends on quantity of volatile solids (VS) excreted and maximum $\mathrm{CH}_{4}$-producing capacity of manure VS $\left(\mathrm{B}_{0}\right)$. Diets of dairy cow have a direct effect on the amount and degradability of excreted VS (Doreau et al., 2014; Møller et al., 2014; Massé et al., 2016; Hassanat and Benchaar, 2019). Forages are the main component in dairy cow diets. Forage digestibility is affected by several factors, but mainly by the content and ruminal degradability of fiber. For instance, brown midrib corn silage (BMCS) is characterized by lower lignin concentration and higher ruminal degradability of fiber, compared with conventional corn silage (CCS). Feeding more digestible forages can influence the amount and the chemical composition (NDF, ADL, and total $\mathrm{N}$ concentrations) of VS of manure.

In a recent study, Hassanat et al. (2017) observed that cows fed BMCS had similar enteric $\mathrm{CH}_{4}$ emissions (g/d) as cows fed CCS, but DMI and milk yield were higher for cows consuming BMCS than for cows fed CCS. Consequently, $\mathrm{CH}_{4}$ production expressed on a DMI or milk production basis was reduced. However, an increase in DMI may result in an increase in VS excretion, which is associated with higher $\mathrm{CH}_{4}$ emission of manure (IPCC 2006). To the best of our knowledge, only 3 studies (Møller et al., 2014; Massé et al., 2016; 
Hassanat and Benchaar, 2019) have investigated the effect of dietary forage source on $\mathrm{CH}_{4}$ emission of manure. Thus, the objective of this study was to assess the effect of replacing CCS with BMCS in the diet on $\mathrm{CH}_{4}$ emissions of stored manure from dairy cows.

\section{MATERIALS AND METHODS}

This study was conducted at the Sherbrooke Research and Development Centre (Sherbrooke, Quebec, Canada). Animal procedures were conducted under the approval of the local Institutional Animal Care Committee and were in accordance with the guidelines of the Canadian Council on Animal Care (CCAC, 2009).

\section{Cows, Experimental Design, and Diets}

The study used 8 multiparous lactating Holstein in a completely randomized design. At the start of the trial, average DIM, BW, and milk yield (mean \pm SD) of cows was $138 \pm 16 \mathrm{~d}, 684 \pm 76.5 \mathrm{~kg}$, and $35 \pm 7.6 \mathrm{~kg} / \mathrm{d}$, respectively. During the trial, cows were housed in individual tiestalls, had free access to water, and were fed (ad libitum; 5\% orts on an as-fed basis) a TMR (65:35, forage:concentrate ratio; on a DM basis) based on either CCS or BMCS (59\% of dietary DM). Chemical composition of the 2 silages and diets (ingredient and chemical) is shown in Table 1 . Cows were allowed 2 wk of adaptation to experimental diets as described in Hassanat et al. (2017).

\section{Feces and Urine Collection}

Total collection of feces and urine was performed over 2 consecutive days by fitting cows with harnesses and tubes allowing the collection of feces and urine separately. Total urine was collected into reinforced plastic containers, whereas feces was collected from reinforced plastic mats placed behind the cow. Feces and urine were weighed daily, sampled (4\% of the amount excreted), mixed based on the daily excreted feces:urine ratio (on a fresh weight basis), and then pooled over the 2 collection days for each cow. Sub-samples were taken and stored at $-20^{\circ} \mathrm{C}$. They were subsequently freezedried and ground to pass a 1-mm screen using a Wiley mill (standard model 4, Thomas Scientific, Swedesboro, NJ) for later determination of DM, VS, NDF, ADF, ADL, and total $\mathrm{N}$ concentrations.

\section{Anaerobic Incubation of Manure}

The mixture of feces and urine of each cow was mixed manually on a fresh weight basis (1:1) with psychrophilic residual sludge obtained from a manure storage structure at the dairy operation of the Sherbrooke Research and Development Centre. The residual sludge had a $\mathrm{pH}$ of 7.38 and was composed (on a DM basis) of $82.1 \% \mathrm{VS}, 43.3 \% \mathrm{NDF}$, and $3.4 \%$ total N. In this study, the mixture of feces, urine, and residual sludge was identified as manure.

The $\mathrm{pH}$ of the manure was measured immediately and a representative sample (50 g) was diluted (1:1)

Table 1. Chemical composition of diets and corn silage conventional and brown midrib cultivars (adapted from Hassanat et al., 2017)

\begin{tabular}{|c|c|c|c|c|}
\hline \multirow{2}{*}{$\begin{array}{l}\text { Item ( } \% \text { of DM, unless } \\
\text { otherwise noted) }\end{array}$} & \multicolumn{2}{|c|}{ Diet $^{1}$} & \multicolumn{2}{|c|}{ Silage $^{1}$} \\
\hline & CCS & BMCS & CCS & BMCS \\
\hline \multicolumn{5}{|l|}{ Ingredient } \\
\hline Conventional corn silage & 58.8 & - & - & - \\
\hline Brown midrib corn silage & - & 58.7 & - & - \\
\hline Timothy hay, chopped & 6.6 & 6.6 & - & - \\
\hline Concentrates $^{2}$ & 34.6 & 34.8 & - & - \\
\hline \multicolumn{5}{|l|}{ Chemical composition } \\
\hline OM & 94.1 & 94.4 & 96.5 & 96.6 \\
\hline $\mathrm{CP}$ & 15.9 & 15.5 & 5.54 & 6.54 \\
\hline NDF & 35.1 & 35.1 & 34.3 & 34.4 \\
\hline $\mathrm{ADF}$ & 19.7 & 19.8 & 20.1 & 20.1 \\
\hline $\mathrm{ADL}(\%$ of $\mathrm{NDF})$ & 6.32 & 5.53 & 7.90 & 6.13 \\
\hline Starch & 16.5 & 17.0 & 26.9 & 28.3 \\
\hline Ether extract & 2.69 & 2.76 & 2.38 & 2.49 \\
\hline Gross energy (Mcal/kg of DM) & 4.36 & 4.37 & 4.37 & 4.38 \\
\hline
\end{tabular}


with water, subsampled $(15 \mathrm{~mL})$, and frozen at $-20^{\circ} \mathrm{C}$ immediately for later determination of VFA concentrations. The manure was also sampled for subsequent determination of DM, VS, and NDF contents. The manure was transferred under anaerobic conditions $\left(\mathrm{O}_{2}\right.$-free $\left.\mathrm{N}_{2}\right)$ into $500-\mathrm{mL}$ glass bottles (6 replicates/ cow; $250 \mathrm{~g}$ in each bottle), sealed with butyl rubber stoppers and aluminum seals (Wheaton, Millville, NJ), and incubated at $20^{\circ} \mathrm{C}$ for $17 \mathrm{wk}$ in a controlled environment chamber. Of the 6 replicates, 3 replicates were used for gas production measurements, whereas 3 other replicates were used for determining fermentation characteristics of manure ( $\mathrm{pH}$ and VFA concentrations). Blank bottles $(\mathrm{n}=3)$ containing residual sludge $(250 \mathrm{~g})$ were treated similarly for measurement of gas production. Thus, in total, 51 bottles were used in this study. Manure was incubated for 17 wk at $20^{\circ} \mathrm{C}$ to simulate the period of the year (late spring, summer, and early fall) in Canada during which the monthly average temperature of the manure storage structure is $20^{\circ} \mathrm{C}$ (Massé et al., 2016). Beyond this period (early spring or late fall), temperature would be considerably lower than $20^{\circ} \mathrm{C}$ and $\mathrm{CH}_{4}$ production from stored manure would decline substantially.

\section{Gas Production Measurement}

Gas pressure in the bottle headspace was measured daily using a digital pressure gauge (0-15 psi $\pm 0.05 \%$; Ashcroft 2089, Ashcroft Inc., Stratford, CT) and the volume of gas produced was calculated according to the following equation:

$$
\mathrm{P}_{1} \mathrm{~V}_{1}=\mathrm{P}_{2} \mathrm{~V}_{2},
$$

where $\mathrm{P}_{1}=$ atmospheric pressure, $\mathrm{V}_{1}=$ volume of gas produced at atmospheric pressure, $\mathrm{P}_{2}=$ pressure of gas measured at specific incubation day, and $\mathrm{V}_{2}=$ volume of headspace of the bottle.

Headspace gas was sampled using a syringe connected to the pressure gauge by a sampling valve. The collected gas sample was then forced into 6-mL screw-capped vacuum vials (Labco Ltd., Lampeter, UK) covered with a rubber septum (National Scientific, Rockwood, TN) for measurement of $\mathrm{CH}_{4}$ concentration. Gas pressure in the bottle head space was then reduced to room pressure by leaving the sampling syringe opened for $2 \mathrm{~min}$. Methane production from blanks was not subtracted from gas produced from the experimental bottles.

After 17 wk of anaerobic incubation, bottles $(\mathrm{n}=3)$ used for gas production measurements were weighed, their contents pooled, and sub-samples were frozen at $-20^{\circ} \mathrm{C}$ for later determination of $\mathrm{DM}, \mathrm{VS}$, and NDF concentrations. Losses of VS and NDF after 17 wk of anaerobic incubation were calculated as the difference between VS and NDF contents at the beginning and at the end of the incubation period.

\section{Fermentation Characteristics of Manure}

Manure from each bottle was sampled under anaerobic weekly up to wk 10 and then on wk 12, 14, and 17 of incubation. Bottle contents were homogenized by swirling, sampled (3.5 g/bottle) using a peristaltic pump (Accu-Jet, BRAND, Wertheim, Germany) and plastic tubing under continuous purging with $\mathrm{O}_{2}$-free $\mathrm{N}_{2}$, and then pooled across replicates. The $\mathrm{pH}$ was measured immediately and a subsample $(5 \mathrm{~mL})$ was stored at $-20^{\circ} \mathrm{C}$ for later determination of VFA concentrations. On wk 17 of incubation, a subsample $(5 \mathrm{~mL})$ of manure was acidified to $\mathrm{pH} 2$ with $50 \%$ sulfuric acid and frozen at $-20^{\circ} \mathrm{C}$ for later determination of $\mathrm{NH}_{3}$ concentrations.

\section{Chemical Analyses}

Dry matter content was determined by drying samples in a vacuum oven at $100^{\circ} \mathrm{C}$ overnight (AOAC, 2005 ; method 934.01). Ash content was determined by incineration at $550^{\circ} \mathrm{C}$ overnight in a muffle furnace (AOAC International, 2005; method 942.05) and the VS content was calculated as the difference between 100 and the percentage of ash. Total $\mathrm{N}$ was determined using the macro-Kjeldahl procedure (AOAC International, 2005; method 954.01). The concentration of NDF was determined as described by Van Soest et al. (1991). The $\mathrm{ADF}$ and ADL contents were determined according to AOAC International (2005; method 973.18). The NDF, $\mathrm{ADF}$, and $\mathrm{ADL}$ procedures were adapted for use in an Ankom200 Fiber Analyzer (Ankom Technology Corp., Fairport, NY). Analysis of VFA was performed using a gas chromatograph equipped with a flame ionization detector and auto-injector (Perkin-Elmer, Norwalk, $\mathrm{CT})$ fitted with DB-FFAP column $(30 \mathrm{~m} \times 0.53 \mathrm{~mm} \times$ $1 \mu \mathrm{m}$; J\&W Scientific, Folsom, CA) with He as the carrier gas. The gas flow in the column was fixed at $5 \mathrm{~mL} /$ min, oven temperature was fixed at $135^{\circ} \mathrm{C}$, and total run time was $8 \mathrm{~min}$. Injector and detector temperatures were 200 and $250^{\circ} \mathrm{C}$, respectively. Gas flows at the detector were 45 and $450 \mathrm{~mL} / \mathrm{min}$ for $\mathrm{H}_{2}$ and air, respectively. Ammonia was determined as in Weatherburn (1967). Analysis of $\mathrm{CH}_{4}$ and $\mathrm{CO}_{2}$ was performed using GC (490 Micro GC, Agilent Technologies, Amstelveen, North Holland, the Netherlands) equipped with a 10 m PPQ column (Agilent Technologies) and a thermal conductivity detector. Column temperature was fixed at $70^{\circ} \mathrm{C}$, while injector and detector temperatures were 
fixed at 110 and $70^{\circ} \mathrm{C}$, respectively. The column was operated at a carrier gas (He) pressure of $138 \mathrm{kPa}$, with elution time of $1 \mathrm{~min}$. Calibration was done using standard gas mixtures containing different proportions of $\mathrm{CH}_{4}$.

\section{Statistical Analyses}

Data were analyzed using the MIXED procedure of SAS (SAS Institute Inc., Cary, NC) and the statistical model included diet as a fixed effect, and cow was the experimental unit. Data of $\mathrm{CH}_{4}$ production were summarized by week. Data of $\mathrm{CH}_{4}$ production and manure $\mathrm{pH}$ were analyzed as repeated measures using the same model with the addition of week and week $x$ diet interactions as fixed effects. The appropriate covariance structure used for repeated-measures analyses was chosen to achieve lowest Akaike, corrected Akaike, and Bayesian information criterion values. Cow within treatment was the subject of the repeated measures. The appropriate covariance structure was specific for each variable measured in repeated measures. Significant effects of treatments were declared at $P \leq 0.05$ and tendencies were declared at $0.05<P \leq 0.10$.

\section{RESULTS AND DISCUSSION}

\section{Chemical Composition of the Mixture of Feces and Urine}

The effect of feeding cows CCS or BMC on the amount excreted and chemical composition of the mixture of feces and urine is presented in Table 2. Cows fed BMCS excreted $31 \%$ more $(P<0.01)$ VS than cows fed CCS $(8.6$ vs. $6.5 \mathrm{~kg})$. This is mainly due to an increase (1.7 $\mathrm{kg} / \mathrm{d}$ ) in $\mathrm{OM}$ intake and no change in OM digestibility (average of $71.3 \%$ ) when cows were fed BMCS versus CCS as reported in Hassanat et al. (2017). The lower lignin concentration in BMCS compared with CCS is the main reason explaining the increase in $\mathrm{OM}$ intake when cows were fed BMCS versus CCS. In agreement, a meta-analysis by Ferraretto and Shaver (2015) showed that feeding cows BMCS versus CCS increases DMI without changing OM digestibility. An increase in DMI without change in OM digestibility would result in an increase in the amount of VS excreted. Other studies reported a positive relationship between OM intake and VS excretion (Hassanat et al., 2013; Massé et al., 2016; Appuhamy et al., 2018).

Concentrations of VS, NDF, ADF, and total $\mathrm{N}$ in feces and urine mixture were not affected by the dietary treatment and averaged $86,52,27$, and $5.4 \%$ on a DM basis, respectively (Table 2). Lignin concentration in the fiber fraction was lower $(P=0.04)$ in the mixture of feces and urine from cows BMCS (9.0\% of NDF) compared with the mixture from cows fed CCS $(10.4 \%$ of NDF). This difference is due to the lower lignin concentration in BMCS compared with CCS (5.5 vs $6.3 \%$ of NDF) because fiber digestibility was not affected by replacing CCS by BMCS in the diet (Hassanat et al., 2017).

\section{Fermentation Characteristics of Incubated Manure}

Interaction between dietary treatment and incubation week was significant $(P<0.01)$ only for manure $\mathrm{pH}$. Indeed, manure of cows fed BMCS had lower $\mathrm{pH}$ on wk 2 of incubation (6.94 vs. 7.16; $P=0.01$ ) and higher $\mathrm{pH}$ on wk 14 of incubation ( 7.98 vs. $7.79 ; P=0.02)$ compared with manure of cows fed CCS (Figure 1). Overall, manure $\mathrm{pH}$ averaged 7.70 (Table 3). This $\mathrm{pH}$ sustains growth and activity of acidogen, acetogen, and methanogen populations in stored manure (Angelidaki et al., 2003; Pind et al., 2003). Concentration of total VFA tended to be higher $(P=0.07)$ in manure of cows fed BMCS compared with manure of cows fed CCS $(55.4$ vs. $41.8 \mathrm{mM})$. In contrast, acetate concertation in manure was not affected by corn silage cultivar in the diet and averaged $33.5 \mathrm{mM}$ (Table 3). Concentrations of propionate and other minor VFA were higher $(P \leq$ $0.03)$ in manure of cows fed BMCS compared with cows fed CCS.

At the end of the incubation period, $\mathrm{NH}_{3}$ concentration of manure was not affected by replacing CCS with BMCS in the diet and averaged $79 \%$ of total N (Table 4). Up to $85 \%$ of manure $\mathrm{N}$ can be in the form of $\mathrm{NH}_{3}$ after an extended period of storage (Petersen, 2018).

\section{Methane Production of Manure}

Methane production (L/kg of VS) of manure throughout the $17 \mathrm{wk}$ of anaerobic incubation is presented

Table 2. Volatile solids and composition of the mixture of feces and urine from lactating cows fed diets based on conventional corn silage (CCS) or brown midrib corn silage (BMCS)

\begin{tabular}{|c|c|c|c|c|}
\hline \multirow[b]{2}{*}{ Item } & \multicolumn{2}{|c|}{ Diet } & \multirow[b]{2}{*}{ SEM } & \multirow[b]{2}{*}{$P$-value } \\
\hline & CCS & BMCS & & \\
\hline \multicolumn{5}{|l|}{ Volatile solids } \\
\hline $\mathrm{kg} / \mathrm{d}$ & 6.54 & 8.55 & 0.324 & $<0.01$ \\
\hline$\%$ of DM & 86.4 & 86.3 & 0.17 & 0.71 \\
\hline \multicolumn{5}{|l|}{ Composition } \\
\hline NDF (\% DM) & 51.8 & 51.8 & 0.62 & 0.99 \\
\hline $\operatorname{ADF}(\% \mathrm{DM})$ & 27.1 & 26.1 & 0.49 & 0.22 \\
\hline $\mathrm{ADL}(\% \mathrm{NDF})$ & 10.38 & 8.95 & 0.384 & 0.04 \\
\hline Total N (\% DM) & 5.52 & 5.25 & 0.176 & 0.32 \\
\hline
\end{tabular}




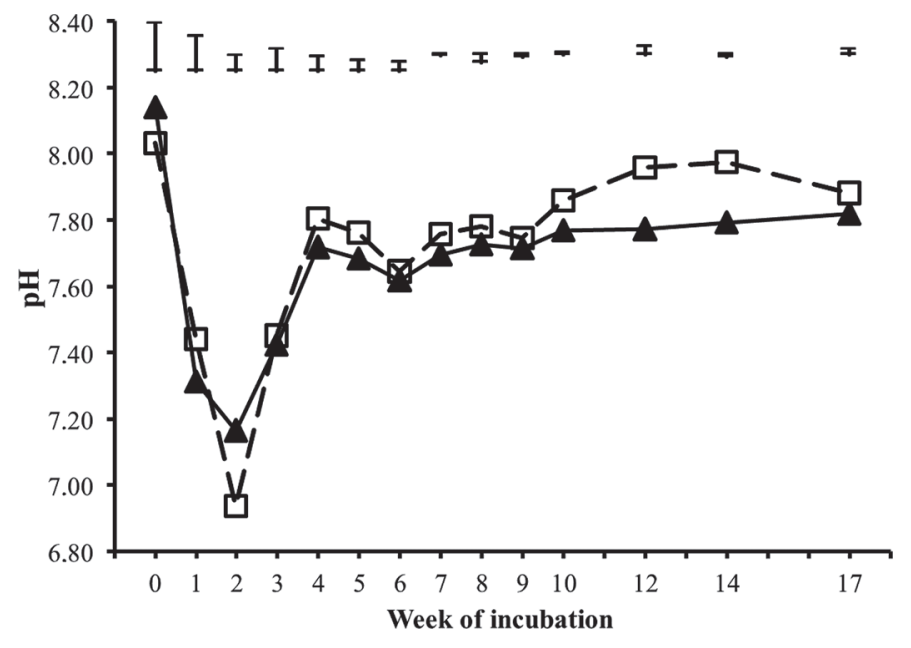

Figure 1. Changes in $\mathrm{pH}$ of incubated manure from lactating cows fed diets based on conventional corn silage $(\mathbf{\Lambda})$ or brown midrib corn silage $(\square)$. Error bars indicate SEM.

in Figure 2. A significant interaction $(P<0.01)$ was observed between corn silage cultivar and incubation week. Methane production started from the onset of incubation. From the onset of incubation up to wk $4, \mathrm{CH}_{4}$ production of manure was not affected by corn silage cultivar. However, from wk 5 to 17, manure from cows fed BMCS produced more $\mathrm{CH}_{4}(P \leq 0.04)$ than manure from cows fed CCS. Peak of $\mathrm{CH}_{4}$ production of manure was observed at wk 5 of incubation: 19.4 and $25.1 \mathrm{~L} / \mathrm{kg}$ of VS for cows fed CCS and BMCS, respectively (data not shown).

After 17 wk of incubation, manure from cows fed BMCS produced $19 \%$ more $\mathrm{CH}_{4}(P=0.01)$ than manure from cows fed CCS (173 vs. $146 \mathrm{~L} / \mathrm{kg}$ of VS; Table 4). This is principally due to lower lignin concentration in manure from cows fed BMCS compared with manure from cows fed CCS, which allowed more extensive fiber degradation during anaerobic incubation of manure.
Table 3. Fermentation characteristics of manure from lactating cows fed diets based on conventional corn silage (CCS) or brown midrib corn silage (BMCS)

\begin{tabular}{|c|c|c|c|c|}
\hline \multirow[b]{2}{*}{ Item } & \multicolumn{2}{|c|}{ Diet } & \multirow[b]{2}{*}{ SEM } & \multirow[b]{2}{*}{$P$-value } \\
\hline & CCS & BMCS & & \\
\hline $\mathrm{pH}$ & 7.67 & 7.72 & 0.07 & 0.13 \\
\hline Total VFA $(\mathrm{m} M)$ & 41.8 & 55.4 & 4.37 & 0.07 \\
\hline Acetate $(\mathrm{m} M)$ & 29.6 & 37.3 & 3.63 & 0.18 \\
\hline Propionate $(\mathrm{m} M)$ & 9.7 & 14.2 & 1.08 & 0.01 \\
\hline Minor $\operatorname{VFA}^{1}(\mathrm{~m} M)$ & 2.59 & 3.89 & 0.307 & 0.03 \\
\hline
\end{tabular}

${ }^{1}$ Minor VFA include iso-butyrate, butyrate, iso-valerate, valerate, and caproate.

Under similar experimental conditions, Hassanat and Benchaar (2019) observed higher maximal $\mathrm{CH}_{4}$ production potential (L/kg of VS) associated with lower lignin concentration in manure of cows fed corn silage-based diets compared with red clover silage-based diets. According to Triolo et al. (2011) and Kafle and Chen (2016), a strong negative relationship $\left(\mathrm{R}^{2}=0.91\right.$ and 0.85 , respectively) exists between lignin concentration in manure and $\mathrm{CH}_{4}$ emissions. Results of this study clearly show the effect of the diet on manure VS chemical composition, and its consequent effect on $\mathrm{CH}_{4}$ production of manure.

The IPCC (2006) suggested a default value $(240 \pm$ $36 \mathrm{~L} / \mathrm{kg}$ of VS) of maximal $\mathrm{CH}_{4}$-producing capacity of manure to calculate $\mathrm{CH}_{4}$ emissions of manure of dairy cows in North America. However, this approach does not take into consideration changes in the chemical composition of manure VS as affected by the type of diet fed to dairy cows. Values of maximal $\mathrm{CH}_{4}$ production potential of manure reported in this study (146 and $173 \mathrm{~L} / \mathrm{kg}$ of VS) are within the range of values (85-197 $\mathrm{L} / \mathrm{kg}$ of VS) observed in previous studies (Massé et al., 2016; Hassanat and Benchaar, 2019) under similar experimental conditions (17 wk of anaerobic incubation; $\left.20^{\circ} \mathrm{C}\right)$.

Table 4. Methane emissions, volatile solid (VS) and NDF losses, and $\mathrm{NH}_{3}$ concentration of incubated manure from lactating cows fed diets based on conventional corn silage (CCS) or brown midrib corn silage (BMCS)

\begin{tabular}{lcccr}
\hline & \multicolumn{2}{c}{ Diet } & & \\
\cline { 2 - 3 } Item & CCS & BMCS & SEM & $P$-value \\
\hline $\mathrm{CH}_{4}$ & & & & \\
$\quad$ Maximal production (L/kg of VS) & 146 & 173 & 5.4 & 0.01 \\
Emissions (g/d) & 128 & 198 & 9.20 & $<0.01$ \\
VS loss (\%) & 30.6 & 37.6 & 1.26 & 0.01 \\
$\mathrm{NDF}$ loss (\%) & 31.2 & 46.2 & 2.79 & 0.01 \\
$\mathrm{NH}_{3}$ & & & & \\
$\mathrm{~m} M$ & 240 & 227 & 5.5 & 0.17 \\
$\%$ of $\mathrm{N}$ & 78.9 & 79.3 & 1.55 & 0.87 \\
\hline
\end{tabular}

${ }^{1}$ Calculated according to equation 10.23 (IPCC, 2006) using VS excretion (Table 2), $\mathrm{CH}_{4}$ maximal production $\left(\mathrm{L} / \mathrm{kg}\right.$ of VS) of manure from cows, and the $\mathrm{CH}_{4}$ conversion factor as suggested by Environment Canada (2015b). 


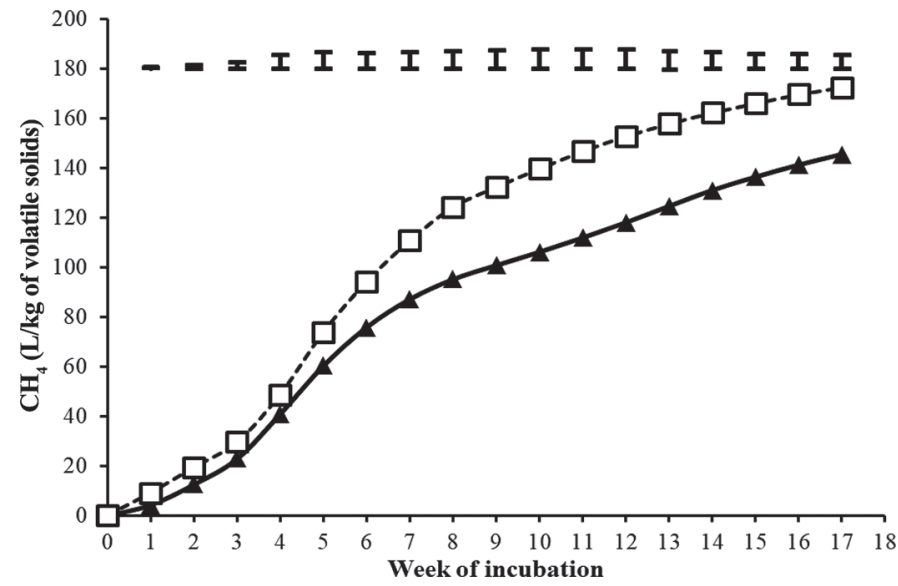

Figure 2. Methane emissions of incubated manure from lactating cows fed diets based on conventional corn silage $(\boldsymbol{\Delta})$ or brown midrib corn silage $(\square)$. Error bars indicate SEM.

Daily manure $\mathrm{CH}_{4}$ emissions (Table 4 ) were calculated with equation 10.23 of the IPCC (2006) as follows:

manure $\mathrm{CH}_{4}$ emission $=\mathrm{VS} \times \mathrm{B}_{0} \times 0.67 \times \mathrm{MCF}$,

where manure $\mathrm{CH}_{4}$ emission is the daily manure $\mathrm{CH}_{4}$ emission per cow $(\mathrm{g} / \mathrm{d})$, VS is the quantity $(\mathrm{kg} /$ cow per d) of VS reported in Table $2, \mathrm{~B}_{0}$ is the maximal $\mathrm{CH}_{4}$ production potential $(\mathrm{L} / \mathrm{kg}$ of $\mathrm{VS}$ ) reported in Table 4, 0.67 is the conversion factor of $\mathrm{L}$ of $\mathrm{CH}_{4}$ to $\mathrm{g}$ of $\mathrm{CH}_{4}$, and $\mathrm{MCF}$ is the methane conversion factor (0.2) for liquid manure suggested by Environment Canada (2015b).

Manure from cows fed BMCS produced $55 \%$ more $(P<0.01) \mathrm{CH}_{4}$ than manure from cows fed CCS $(198$ vs. $128 \mathrm{~g} / \mathrm{d}$; Table 4). The higher daily manure $\mathrm{CH}_{4}$ emissions from of cows fed BMCS diet compared with emissions from cows fed CCS are due to the higher VS excretion $(\mathrm{kg} / \mathrm{d})$ and the higher maximal $\mathrm{CH}_{4}$ production $(\mathrm{L} / \mathrm{kg}$ of $\mathrm{VS}$ ) for cows fed BMCS versus cows fed CCS. In our previous study (Hassanat et al., 2017), enteric $\mathrm{CH}_{4}$ emission of cows fed BMCS and or CCS were 470 and $483 \mathrm{~g} / \mathrm{d}$, respectively. Thus, total $\mathrm{CH}_{4}$ emissions (sum of enteric and manure emissions) were 668 and $611 \mathrm{~g} / \mathrm{d}$ for cows fed BMCS and CCS, respectively. Calculated manure $\mathrm{CH}_{4}$ emissions of cows fed BMCS and CCS represent 30 and $21 \%$ of the total emissions, respectively, which is within the range of emissions reported in other studies (Doreau et al., 2014; Hassanat and Benchaar, 2019). Compared with CCS, feeding cows BMCS did not significantly affect enteric $\mathrm{CH}_{4}$ emissions $(-13 \mathrm{~g} / \mathrm{d})$, but increased manure $\mathrm{CH}_{4}$ emissions by $70 \mathrm{~g} / \mathrm{d}$, resulting in a net increase in total $\mathrm{CH}_{4}$ emissions by $57 \mathrm{~g} / \mathrm{d}(+9 \%)$.
Degradation of VS and NDF (i.e., VS and NDF losses) during incubation (Table 4) was more extensive $(P<0.01)$ in manure from cows fed BMCS compared with manure from cows fed CCS diet (38 and 46 versus 31 and $31 \%$, respectively). This is consistent with differences in $\mathrm{CH}_{4}$ emissions observed between manure from cows fed BMCS compared with cows fed CCS. In agreement, Aguerre et al. (2012) and Hassanat and Benchaar (2019) reported up to $33 \%$ VS losses of stored manure. Niu et al. (2017) also reported $40 \%$ carbon loss from manure stored for $29 \mathrm{wk}$. Maximum methane production potential expressed on kilogram of degraded VS basis averaged $467 \mathrm{~L} / \mathrm{kg}$ of VS and were not affected by corn silage cultivar. This value is within the range of values (450-850 L/ kg of VS degraded) estimated by Lory et al. (2010).

\section{CONCLUSIONS}

Results of this study show that manure contribution to $\mathrm{CH}_{4}$ emissions may increase when more digestible forages are used in dairy cow diets. Compared with CCS, feeding BMCS to dairy cows increased VS excretion $(\mathrm{kg} / \mathrm{d})$ and maximal methane production $(\mathrm{L} / \mathrm{kg}$ of VS) when manure was incubated under anaerobic conditions for $17 \mathrm{wk}$. Therefore, it is necessary to assess $\mathrm{CH}_{4}$ emissions from stored manure when dietary $\mathrm{CH}_{4}$ mitigation options are suggested to ensure reductions in enteric $\mathrm{CH}_{4}$ do not increase $\mathrm{CH}_{4}$ emissions from stored manure. In this case, strategies to reduce or eliminate $\mathrm{CH}_{4}$ emissions from stored manure should be considered.

\section{ACKNOWLEDGMENTS}

The authors express their appreciation to L. Croteau and S. Provencher (technical assistance) and the barn crew (care of animals) from the Sherbrooke Research and Development Centre (Agriculture and Agri-Food Canada, Ottawa, ON, Canada). The authors acknowledge funding support of Agriculture and Agri-Food Canada.

\section{REFERENCES}

Aguerre, M. J., M. A. Wattiaux, T. Hunt, and N. E. Lobos. 2012. Effect of nitrogen content and additional straw on changes in chemical composition, volatile losses, and ammonia emissions from dairy manure during long-term storage. J. Dairy Sci. 95:3454-3466. https://doi.org/10.3168/jds.2011-4839.

Angelidaki, I., L. Ellegaard, and B. K. Ahring. 2003. Applications of the anaerobic digestion process. Pages 1-33 in Biomethanation I. Vol. 81. B. K. Ahring, ed. Springer, Berlin, Germany. https://doi .org/10.1007/3-540-45839-5.

AOAC International. 2005. Official Methods of Analysis. 18th ed. AOAC, Arlington, VA. 
Appuhamy, J., L. E. Moraes, C. Wagner-Riddle, D. P. Casper, and E. Kebreab. 2018. Predicting manure volatile solid output of lactating dairy cows. J. Dairy Sci. 101:820-829. https://doi.org/10 $.3168 /$ jds. $2017-12813$

Beauchemin, K. A., T. A. McAllister, and S. McGinn. 2009. Dietary mitigation of enteric methane from cattle. Perspect. Agric. Vet. Sci. Nutr. Nat. Resour. 4:1-18. https://doi.org/10.1079/ pavsnnr20094035.

Benchaar, C., F. Hassanat, R. Gervais, P. Y. Chouinard, H. V. Petit, and D. I. Massé. 2014. Methane production, digestion, ruminal fermentation, nitrogen balance, and milk production of cows fed corn silage- or barley silage-based diets. J. Dairy Sci. 97:961-974. https://doi.org/10.3168/jds.2013-7122.

CCAC (Canadian Council on Animal Care). 2009. CCAC guidelines on: the care and use of farm animals in research, teaching and testing. Canadian Council on Animal Care, Ottawa, ON, Canada.

Doreau, M., A. Ferlay, Y. Rochette, and C. Martin. 2014. Effects of dehydrated lucerne and soya bean meal on milk production and composition, nutrient digestion, and methane and nitrogen losses in dairy cows receiving two different forages. Animal 8:420-430. https://doi.org/10.1017/S1751731113002206.

Environment Canada. 2015a. Greenhouse Gas Sources and Sinks in Canada. National Inventory Report 1990-2013 Part 3. Environment Canada, Ottawa, ON.

Environment Canada. 2015b. Greenhouse Gas Sources and Sinks in Canada. National Inventory Report 1990-2013 Part 2. Environment Canada, Ottawa, ON.

Ferraretto, L. F., and R. D. Shaver. 2015. Effects of whole-plant corn silage hybrid type on intake, digestion, ruminal fermentation, and lactation performance by dairy cows through a meta-analysis. J. Dairy Sci. 98:2662-2675. https://doi.org/10.3168/jds.2014-9045.

Hassanat, F., and C. Benchaar. 2019. Methane emissions of manure from dairy cows fed red clover- or corn silage-based diets supplemented with linseed oil. J. Dairy Sci. 102. https://doi.org/10 .3168/jds.2018-16014

Hassanat, F., R. Gervais, and C. Benchaar. 2017. Methane production, ruminal fermentation characteristics, nutrient digestibility, nitrogen excretion, and milk production of dairy cows fed conventional or brown midrib corn silage. J. Dairy Sci. 100:2625-2636. https:// doi.org/10.3168/jds.2016-11862.

Hassanat, F., R. Gervais, C. Julien, D. I. Massé, A. Lettat, P. Y. Chouinard, H. V. Petit, and C. Benchaar. 2013. Replacing alfalfa silage with corn silage in dairy cow diets: Effects on enteric methane production, ruminal fermentation, digestion, $\mathrm{N}$ balance, and milk production. J. Dairy Sci. 96:4553-4567. https://doi.org/10 $.3168 /$ jds.2012-6480.

IPCC (Intergovernmental Panel on Climate Change). 2006. Emissions from livestock and manure management. In Guidelines for Green House Inventories. Vol. 4. Intergovernmental Panel on Climate Change (IPCC).
Kafle, G. K., and L. Chen. 2016. Comparison on batch anaerobic digestion of five different livestock manures and prediction of biochemical methane potential (BMP) using different statistical models. Waste Manag. 48:492-502. https://doi.org/10.1016/j.wasman .2015.10.021.

Lory, J. A., R. E. Massey, and J. M. Zulovich. 2010. An evaluation of the USEPA calculations of greenhouse gas emissions from anaerobic lagoons. J. Environ. Qual. 39:776-783. https://doi.org/10 $.2134 /$ jeq2009.0319.

Massé, D. I., G. Jarret, F. Hassanat, C. Benchaar, and N. M. C. Saady. 2016. Effect of increasing levels of corn silage in an alfalfa-based dairy cow diet and of manure management practices on manure fugitive methane emissions. Agric. Ecosyst. Environ. 221:109-114. https://doi.org/10.1016/j.agee.2016.01.018.

Møller, H. B., V. Moset, M. Brask, M. R. Weisbjerg, and P. Lund. 2014. Feces composition and manure derived methane yield from dairy cows: Influence of diet with focus on fat supplement and roughage type. Atmos. Environ. 94:36-43. https://doi.org/10 .1016/j.atmosenv.2014.05.009.

Niu, M., J. A. D. R. N. Appuhamy, R. S. Dungan, E. Kebreab, and A. B. Leytem. 2017. Effects of diet and manure storage method on carbon and nitrogen dynamics during storage and plant nitrogen uptake. Agric. Ecosyst. Environ. 250:51-58. https://doi.org/ 10.1016/j.agee.2017.08.034

Petersen, S. O. 2018. Greenhouse gas emissions from liquid dairy manure: Prediction and mitigation. J. Dairy Sci. 101:6642-6654. https://doi.org/10.3168/jds.2017-13301.

Pind, P. F., I. Angelidaki, B. K. Ahring, K. Stamatelatou, and G. Lyberatos. 2003. Monitoring and control of anaerobic reactors. Pages 135-182 in Biomethanation II. Vol. 82. B. K. Ahring, ed. Springer, Berlin, Germany. https://doi.org/10.1007/3-540-45838-7

Triolo, J. M., S. G. Sommer, H. B. Møller, M. R. Weisbjerg, and X. Y. Jiang. 2011. A new algorithm to characterize biodegradability of biomass during anaerobic digestion: Influence of lignin concentration on methane production potential. Bioresour. Technol. 102:9395-9402. https://doi.org/10.1016/j.biortech.2011.07.026.

van Gastelen, S., E. C. Antunes-Fernandes, K. A. Hettinga, G. Klop, S. J. J. Alferink, W. H. Hendriks, and J. Dijkstra. 2015. Enteric methane production, rumen volatile fatty acid concentrations, and milk fatty acid composition in lactating Holstein-Friesian cows fed grass silage- or corn silage-based diets. J. Dairy Sci. 98:1915-1927. https://doi.org/10.3168/jds.2014-8552.

Van Soest, P. J., J. B. Robertson, and B. A. Lewis. 1991. Methods for dietary fiber, neutral detergent fiber, and nonstarch polysaccharides in relation to animal nutrition. J. Dairy Sci. 74:3583-3597. https://doi.org/10.3168/jds.S0022-0302(91)78551-2.

Weatherburn, M. 1967. Phenol-hypochlorite reaction for determination of ammonia. Anal. Chem. 39:971-974. https://doi.org/10 $.1021 /$ ac60252a045. 